\title{
Effect of zinc as a foliar spray on growth and flower production of Marigold (Tagetes erecta L.)
}

\author{
Syed Tanveer Shah ${ }^{1}$, Sami Ullah ${ }^{1}$, Nadeem Khan ${ }^{1 *}$, Muhammad Sajid ${ }^{1}$, \\ Abdur Rab ${ }^{1}$, Noor Ul Amin ${ }^{1}$, Asif Iqbal ${ }^{2}$, Ahmad Naeem ${ }^{1}$, Mazhar \\ Iqbal $^{3}$, Saeed Ul Haq ${ }^{1}$, Shahid Rahman ${ }^{1}$, Fawad Ali Shah ${ }^{2}$ and Said \\ Rawan $^{1}$ \\ 1. Department of Horticulture, The University of Agriculture, Peshawar-25130- Pakistan \\ 2. Department of Agronomy, The University of Agriculture, Peshawar-Pakistan \\ 3. Department of Botany, SBB University Sheringal, Dir-Upper-Pakistan \\ *Corresponding author's email: nadeemaup@ yahoo.com \\ Citation \\ Syed Tanveer Shah, Sami Ullah, Nadeem Khan, Muhammad Sajid, Abdur Rab, Noor Ul Amin, Asif Iqbal, Ahmad \\ Naeem, Mazhar Iqbal, Saeed Ul Haq, Shahid Rahman, Fawad Ali Shah and Said Rawan. Effect of zinc as a foliar \\ spray on growth and flower production of Marigold (Tagetes erecta L.). Pure and Applied Biology. Vol. 5, Issue 4, \\ pp738-743. http://dx.doi.org/10.19045/bspab.2016.50092
}

Received: 30/03/2016

Revised: 30/06/2016

Accepted: 10/07/2016

Online First: 08/08/2016

\section{Abstract}

An experiment was conducted to checked, the response of Marigold (Tagetes erecta L.) to foliar spray of zinc on growth and flower production at the Ornamental Horticulture Nursery, Department of Horticulture, The University of Agriculture Peshawar during 2014. The experiment was laid out at Completely Randomized Design (CRD) with one factor repeated three times. In this study Marigold plants were sprayed with five level of zinc sulphate $(0,0.3$, $0.5,0.7$ and $0.9 \%$ ). Result revealed that most of the traits were significantly affected by zinc while leaf area showed non-significant differences. Maximum plant height $(25.84 \mathrm{~cm})$, stem diameter $(0.75 \mathrm{~cm})$, number of flower plant ${ }^{-1}(14.66)$, fresh flower weight $(4.67 \mathrm{gm})$, number of branches plant ${ }^{-1}$ (23.22) and number of leaves branches ${ }^{-1}$ (40.36) were recorded at $0.5 \%$ Zinc sulphate application. So, it is concluded that $0.5 \%$ Zinc should be spray good for quality flower production of Marigold flowers, hence recommended for the farmers of the agro-climatic condition of Peshawar.

Key words: Marigold; Zinc; Growth; Production; Foliar

\section{Introduction}

Marigold botanically known as Tagetes erecta L. belongs to the family Asteraceae. It has easily culture and adoptability. Commercially grown flower plant that is gaining worldwide popularity and increasing the demand [1]. These marigold flowers are sold in the market as loose flowers in bulks, garland and especially cut flowers. For protein synthesis, regularity of many coenzymes, photosynthesis, cell division, maintenance of membrane structure and sexual fertilization zinc play important role [2]. Zinc after iron involve in various 
biological process in many organisms [3]. It is important micronutrient for plant growth and development. The supply of this nutrient improves the quality flower production [4], [5]. Foliar application of micronutrients directly affects the quality and yield [6]. In optimum concentration zinc increasing plant height, number of flowers, flower diameter and flower yield. Otherwise, increase doses than normal cause stunted growth of the plant [7]. [8] Zinc improve the biological machines, and these are consist of proteins and enzymes. Foliar application on plants functional the leaves and leaves are green factories where as many chemical process of photosynthesis that produce the compounds, are required for plant growth [9]. These establishment processes of nutrient application improve nutrient utilization and lower environmental pollution. These nutrients pass to the plant body easily and where its require [10]. In this study, we will a report about main characteristics of flowering of marigold under application of zinc sulphate in foliar spray application.

\section{Materials and Methods}

This experiment was conducted to find out the effect of foliar application of Zinc on Marigold, at the Ornamental Horticulture Nursery, Department of Horticulture, The University of Agriculture Peshawar during 2014.

\section{Planting Materials}

The experiment was conducted with a Completely Randomized Design (CRD) with one factor repeated three times. The local variety of marigold (Tagetes erecta) was selected. The seedlings were taken from "Elite Nursery" Peshawar. Seeds were sown on 17th August and seeds were germinated up to 25th August 2014. On 27th August 2014 seedlings were transplanted when reached at 3-4 true leaves stages to wellprepared plastic bags. Bag size is $15 \mathrm{~cm}$ diameter which contains farm soil. Zinc levels $(0,0.3,0.5,0.7$ and $0.9 \%)$ were applied to plants through foliar spray. For each treatment the five plants are kept in one plot and total twenty five numbers of plants in each replication. All the cultural practice such as (pest control, irrigation, hoeing and weeding etc) was kept constant. The following growth attributes were studied during the course of the experiment.

\section{Plant Height (cm)}

Plant height was measure with measuring tape from three plants and then their average was calculated.

\section{Stem diameter $(\mathrm{cm})$}

Diameter of the stem of three randomly selected plants from all treatment in each replication was measured with the help of vernier caliper.

\section{Branches plant $^{-1}$}

Sampling the branches from three plants and average was calculated.

\section{Leaves branch ${ }^{-1}$}

Number of leaves per branch was counted from three randomly selected plants from each treatment.

\section{Leaf area $\left(\mathrm{cm}^{2}\right)$}

Leaf area was determined with the help of Leaf area machine and average was calculated.

\section{Number of flowers plant ${ }^{-1}$}

Flowers were counted from three randomly selected plants and average was calculated.

\section{Flower fresh weight (gm)}

From each treatment three plants were randomly selected, the fresh weight was determined by digital weight balance and average was calculated.

\section{Statistical Analysis}

Analysis of the parameters was determined through statistical software [11].

\section{Results and discussions}

Plant height (cm)

Plant height $(\mathrm{cm})$ was significantly affected by foliar spray of zinc (Table-1). By the comparison of means, we came to know that maximum plant height $(25.84 \mathrm{~cm})$ was recorded at $(0.5 \%)$ zinc, while minimum 
plant height $(17.73 \mathrm{~cm})$ was observed in control treatment $(0 \%)$ zinc. Foliar spray of $\mathrm{Zn}$ significantly increased plant height of Gerbera [12], increased height of Iris plants [13]. Similar results were observed by [14] in pot marigold. The result of [15] expressed that, the use of foliar fertilizers stimulate plant growth and better development of plants, leads to the increase in morphological characters such as plant height.

\section{Stem diameter $(\mathrm{cm})$}

Data presenting that, different zinc level had a significant effect on stem diameter $(\mathrm{cm})$ of marigold plant (Table-1). By the comparison of means, we came to know that maximum stem diameter $(0.75 \mathrm{~cm})$ was recorded at $(0.5 \%)$ zinc, while minimum stem diameter $(0.02 \mathrm{~cm})$ was observed in control treatment $(0 \%)$ zinc. which was statistically similar with stem diameter $(0.03 \mathrm{~cm})$ at 0.3 and $0.7 \%$ respectively. It may be due to zinc is an essential constituent of cell component and constituents of the various cell membranes that are also important for the maintenance of cell structure and induce cell division resulted enhanced the vegetative growth like stem diameter [16]. The improvements in these characters might be due to enhancement in vegetative growth which is likely to be responsible for more accumulation of photosynthetic materials, hence resulted in giving maximum value in these characters. These findings are very similar to the findings of [17] and [18] in chrysanthemum.

\section{Number of branches plant ${ }^{-1}$}

Different Zinc level had a significant effect on number of branches plant ${ }^{-1}$ of marigold plant. As regarding foliar application of zinc, more number of branches plant $^{-1}$ (23.22) was recorded at $(0.5 \%)$. While less number of branches plant ${ }^{-1}$ (12.33) was observed in control treatment $\left(\begin{array}{ll}0 & \%\end{array}\right)$. Spraying of zinc significantly affect number of branches, the result are similar with the [19] reported that, number of branches increase in anise (Pimpinella anisum).

Number of leaves branch ${ }^{-1}$

The statistical analysis of the data revealed that Zinc level had a significant effect on number of leaves plant ${ }^{-1}$ of marigold plant. As regarding foliar application of zinc, more number of leaves branch ${ }^{-1}$ (40.36) was recorded at $(0.5 \%)$. While less number of leaves branch ${ }^{-1}$ (30.66) was observed in control treatment $(0 \%)$. Foliar application of $\mathrm{ZnSO}_{4}$ significantly increased the number of leaves per plant in Iris [13]. Similarly, [12] observed a significantly higher number of leaves per plant in Gerbera due to foliar application of $\mathrm{Zn}$. [20] reported that, spraying Antholyza aethiopica with $\mathrm{Zn}$ had a promoting effect on increasing the leaf number per plant.

Table 1. Effect of zinc level on plant height $(\mathrm{cm})$, stem diameter, number of branches plant , number of leaves branch ${ }^{-1}$ of marigold plant

\begin{tabular}{|c|c|c|c|c|}
\hline Zinc Levels & \multicolumn{4}{|c|}{ Parameters } \\
\cline { 2 - 5 } & $\begin{array}{l}\text { Plant } \\
\text { Height }\end{array}$ & $\begin{array}{c}\text { Stem } \\
\text { Diameter }\end{array}$ & $\begin{array}{c}\text { Number of Branches } \\
\text { Plant }^{-1}\end{array}$ & $\begin{array}{c}\text { Number of leaves } \\
\text { branch-1 }^{-1}\end{array}$ \\
\hline 0 & $17.73 \mathrm{c}$ & $0.02 \mathrm{c}$ & $12.33 \mathrm{c}$ & $30.66 \mathrm{~d}$ \\
\hline $0.3 \%$ & $22.50 \mathrm{~b}$ & $0.03 \mathrm{bc}$ & $17.33 \mathrm{~b}$ & $33.66 \mathrm{c}$ \\
\hline $0.5 \%$ & $25.84 \mathrm{a}$ & $0.07 \mathrm{a}$ & $23.22 \mathrm{a}$ & $40.36 \mathrm{a}$ \\
\hline $0.7 \%$ & $22.41 \mathrm{~b}$ & $0.03 \mathrm{bc}$ & $17.11 \mathrm{~b}$ & $33.11 \mathrm{c}$ \\
\hline $0.9 \%$ & $22.67 \mathrm{~b}$ & $0.04 \mathrm{~b}$ & $18.22 \mathrm{~b}$ & $35.66 \mathrm{~b}$ \\
\hline LSD $(\mathrm{P}<0.05)$ & 2.21 & 0.01 & 3.35 & 1.65 \\
\hline
\end{tabular}

Means followed by varying letter significantly differ at $5 \%$ level of significance 


\section{Leaf area $\left(\mathrm{cm}^{2}\right)$}

Data regarding leaf area $(\mathrm{cm} 2)$ shows that different level of zinc had non-significant effect on the leaf area $(\mathrm{cm} 2)$ of marigold plant (Table 1). However, comparing the means of leaf area, it is clear from the mean table that wider leaves $\left(1.14 \mathrm{~cm}^{2}\right)$ were recorded at $(0.5 \%$ zinc sulphate $)$, while the minimum leaf area $\left(0.94 \mathrm{~cm}^{2}\right)$ was recorded in $0.03 \%$ Zinc application.

\section{Number of flowers plant ${ }^{-1}$}

Different level of Zinc had a significant effect on number of flower plant ${ }^{-1}$ of marigold plant. Comparing the means of number of flowers plant ${ }^{-1}$, it is clear from mean table more number of flower plant ${ }^{-1}$ (14.66) was recorded at $(0.5 \%$ zinc sulphate). While less number of flowers plant $^{-1}(8)$ was observed in control treatment $(0 \%)$. Foliar application of nutrients is in advance more significance in fertilization of various field and floricultural crops, in many countries. The advantages of foliar fertilizers were more noticeable under growing conditions restricting the incorporation of nutrients from the soil, as reported by [21]. Foliar application affect better than soil application on flower production [22]. Biomass of the flower related with zinc [23]. Chlorophyll production, pollen function and fertilization require zinc [24]. Many researchers reported that, zinc had a significant effect on flower production in Gladiolus [25].

\section{Fresh flower weight (gm)}

Zinc levels significantly affect fresh flower weight of marigold plant. Comparing the means of flower weight, it is clear from mean table that maximum fresh flower weight $(4.67 \mathrm{gm})$ was recorded at $(0.5 \%$ zinc sulphate) while minimum flower weight $(2.12 \mathrm{gm})$ was observed in control treatment $(0 \%)$. which was statistically similar with flower weight $(2.67 \mathrm{gm})$ at 0.3 $\%$ respectively. Increase in fresh weight of flowers might be attributed to increased fresh weight of complete stem due to good growth of plants. These findings are in accordance with the results of [26], who observed increase in fresh weight of rose flower as a result of foliar application of micronutrients. [13] also noted Iris flowers fresh weight increase was due to either foliar application of $\mathrm{ZnSO}_{4}$ applied singly.

Table 2. Effect of zinc level on leaf area $\left(\mathrm{cm}^{2}\right)$, number of flower plant ${ }^{-1}$ and fresh weight of marigold plant

\begin{tabular}{|c|c|c|c|}
\hline \multirow{2}{*}{ Zinc Levels } & \multicolumn{3}{|c|}{ Parameters } \\
\cline { 2 - 4 } & $\begin{array}{c}\text { Leaf Area } \\
\left(\mathbf{c m}^{\mathbf{2}}\right)\end{array}$ & $\begin{array}{c}\text { Number of Flowers } \\
\text { Plant }^{-1}\end{array}$ & $\begin{array}{c}\text { Fresh Weight } \\
(\mathbf{g m})\end{array}$ \\
\hline $0 \%$ & 1.13 & $8.00 \mathrm{~d}$ & $2.12 \mathrm{~d}$ \\
\hline $0.3 \%$ & 0.94 & $11.66 \mathrm{~b}$ & $2.67 \mathrm{~cd}$ \\
\hline $0.5 \%$ & 1.14 & $14.66 \mathrm{a}$ & $4.67 \mathrm{a}$ \\
\hline $0.7 \%$ & 0.96 & $10.00 \mathrm{c}$ & $3.57 \mathrm{~b}$ \\
\hline $0.9 \%$ & 1.09 & $10.33 \mathrm{bc}$ & $3.12 \mathrm{bc}$ \\
\hline LSD $(\mathrm{P}<0.05)$ & $\mathrm{Ns}$ & 1.40 & 0.75 \\
\hline
\end{tabular}

Means followed by varying letter significantly differ at $5 \%$ level of significance

\section{Conclusion and recommendation}

From the above results $0.5 \%$ foliar application of Zinc Sulphate shows better for all of the parameters such as plant height, stem diameter, number of flowers plant $^{-1}$, fresh flower weight, branches plant ${ }^{-1}$ and number of leaves branch $^{-1}$, while number leaf area was not positively affected by zinc application. For well growth and quality of flowering zinc performed better 
and recommended at the rate of $0.5 \%$ for marigold.

\section{Authors' contributions}

Conceived and designed the experiments: ST Shah \& S Ullah, Performed the experiments: M Sajid, A Rab \& N Amin, Analyzed the data: M Iqbal, A Naeem \& FA Shah, Contributed reagents/ materials/ analysis tools: A Iqbal, S Rawan, SU Haq \& S Rahman, Wrote the paper: N Khan.

\section{References}

1. Asif M (2008). Effect of Various NPK Levels on Growth, Yield and Xanthophyll Contents of Marigold. MSc Thesis. Inst. Hort. Sci. Univ. Agric. Faisalabad, Pakistan. Pp. 95.

2. Marchner H (1995). Mineral nutrition of higher plants. 2nd ed. Academic Press. London.

3. Broadley MR, White PJ, Hammond I, Zelko \& Lux A (2007). Zinc in plants. New Phytol. 173: 677-702.

4. Gao XP, Zou EQ, Fan XY, Zhang FS \& Hoffland E (2006). From flooded to aerobic conditions in rice cultivation: Consequences for zinc uptake. Plant and Soil 280: 41-47.

5. Medina J, Clavero RI, Gonzalez BM, Galvez FJ, Manuel LAJ \& Soria C (2007). Field performance characterization of strawberry (Fragaria ananassa Duch.) Plants derived from cryopreserved apices. Scientia Hort 113: 28-32.

6. Gobara AA, Ahmed FF \& El-Shamma MS (2001). Effect of varying N. K. and $\mathrm{Mg}$ application ratio on productivity of Banaty grapevines. The fifth Arabian Horticulture conference, Ismallia Egypt Pp. 83-90.

7. Naruk S, Gujar KD \& Lal G (2000). Effect of foliar application of zinc and molybdenum on growth and yield of okra (Abelmoschus esculentus L. Moench) cv. Pusasawani. Haryana $J$ Hort Sci 29: 266-267.
8. Stout PR (1962). Introduction to the micronutrient elements. J Agri Food Chem 10: 170-175.

9. Romemheld V \& El-Fouly MM (1999). Foliar nutrient application, Challenge and limits in crop production, Proc. 2nd International Workshop on "Foliar Fertilization" April 4-10 Bangkok, Thailand. Pp: 1-32.

10. Saqib M, Zor C \& Schubert S (2006). Salt resistant and salt-sensitive wheat genotypes show similar biochemical reaction at protein level in the first phase of salt stress. J Plant Nutri Soil Sci 169: 542-548.

11. Steel RGD, Torrie JH \& Dicky DA (1997). Principles and Procedures of Statistics: A Biometric Approach. 3rd ED. MCGRAW Hill Book Co. Inc. NewYork. Pp. 172 -177.

12. Khosa SS, Younis A, Rayit A, Yasmeen S \& Riaz A (2011). Effect of Foliar Application of Macro and Micro Nutrients on Growth and Flowering of Gerbera jamesonii L. Amer. Euras. J Agri Envio Sci 11: 736-757.

13. Khalifa R, Khan M, Shaaban SHA \& Rawia A (2011). Effect of Foliar Application of Zinc Sulfate and Boric Acid on Growth, Yield and Chemical Constituents of Iris Plants. Ozean $J$ Appl Sci 4: 129-144.

14. Rahmati M, Azizi M, Hassanzadeh MK \& Neamati H (2009). The effects of different level of nitrogen and plant density on the agro morphological characters yield and essential oils content of improved chamomile (Matricaria chamomilla L.) cultivar "Bodegold". J Hort Sci 23(1): 27-35.

15. Dadkhah A, Amini M \& kafi M (2012). The effect of different levels of nitrogen and phosphorus fertilizers on the yield and quality of German chamomile. Iranian J Field Crops Res 10(2): 321326. 
16. Kendra KV, Junagadh \& Gujarat A (2013). Response of chrysanthemum verities to different levels of nitrogen, phosphorus and potash. 3(2): 15841593.

17. John AQ \& Paul TM (1999). Response of Chrysanthemum morifolium Ramat, to different levels of nitrogen and phosphorous. Applied Biol Res 1(1): 35-38.

18. Belgaonkar DV, Bist MA \& Wankade MB (1996). Effect of levels of nitrogen and phosphorus with different spacing on growth and yields of annual chrysanthemum. J Soil Crop 6(2): 154158.

19. Pirzad AR, Tousi P \& Darvishzadeh R (2013). Effect of $\mathrm{Fe}$ and $\mathrm{Zn}$ foliar application on plant characteristics and essential oil content of anise (Pimpinella anisum L.). Iranian J Crop Sci 15(1).

20. El-Khayat AS (1999). The response of growth and yield of Antholyza aethiopica under plants to chilling and foliar potassium and zinc application. Res Bull Moshtohor Egypt 37(3): 19151934.
21. Verma VK (2003). Response of foliar application of nitrogen and gibberelic acid on growth and flowering of Dianthus caryothyllus L. Him, J Agri Res 29(1): 59-64.

22. Tomimori SY, Tashiro Y \& Taniyama T (1995). Exhaust characteristics and Loads of Fertilizer nutrients in drainage from a golf course Japanese. $J$ Crop Sci 64(4): 682-691.

23. Cakmak I (2008). Enrichment of cereal grains with zinc: agronomic or genetic bio fornication, Plant Soil 30(2): 1-17.

24. Kaya M, Atak K, Mahmood C, Ciftc Y\& Ozcan S (2005). Effects of Pre-Sowing Seed Treatment with $\mathrm{Zn}$ and Foliar Spray of Humic Acids on Yield of Common Bean (Phaseolus vulgaris L.). Int J Agri Bio 10: 56-65.

25. Halder NK, Rafiuddin MD, Siddiky MA, Gomes R, Anjuman K \& Begam A (2007). Performance of Gladiolus as influenced by boron and zinc. Pakistan J Biol Sci 10: 581-585.

26. Singh UC \& Bhattacharjee SK (1997). Effect of Pre-harvest Micronutrients on Post Harvest Life of Raktagandha Roses. Ann Agri Res 18: 375-360. 